\title{
Budgetary Institutional Adjustments and Fiscal Discipline in Local Government: An Assessment of Entity Location Mediation
}

\author{
Paul Onyango-Delewa ${ }^{1}$ \\ Isaac Nabeta Nkote ${ }^{2}$
}

RESEARCH

ARTICLE

\begin{tabular}{l} 
ARTICLE INFO \\
\hline Submitted : 05.11.2018 \\
Revised : 03.02.2019 \\
Accepted : 12.03.2019 \\
Available : 30.07 .2019 \\
\hline iThenticate similarity \\
score: 7\% \\
\hline JEL classification: \\
H60, H70, E62 \\
\hline Keywords: \\
Fiscal Discipline, \\
Budgetary Institutional \\
Adjustments, Location
\end{tabular}

ARTICLE INFO

Submitted : 05.11 .2018

Revised : 03.02.2019

Accepted : 12.03.2019

iThenticate similarity score: $7 \%$

JEL classification

$\mathrm{H} 60, \mathrm{H} 70, \mathrm{E} 62$

Keywords:

Budgetary Institutional

Adjustments, Location

\begin{abstract}
A B S T R A C T
For quite a long time, budgetary institutional adjustments have been implicated as important determinants of fiscal discipline in local government. Moreover, entity location has been argued a pivotal and influential factor in the budgetary institutional adjustments-fiscal discipline linkages. However, to date no research is conclusive enough on what precisely explains budget discipline especially in Sub-Saharan Africabased localities. On the basis of a cross-sectional research design, this study investigated the budgetary institutional adjustments-entity locationfiscal discipline triangulation in Uganda, East Africa. Data were collected from 26 districts, 9 municipalities and a number of sub-counties spread across four purposively-selected geographical regions of the country. The regions are north-western, northern, north-eastern, and eastern. Data were then subjected to both regression and structural equation modeling statistical analysis. Notably, results from structural equation modeling revealed that budgetary institutional adjustments have strong predictive power on fiscal discipline. Conversely, entity location does not have any influence on the budgetary institutional adjustments-fiscal discipline relationship. Theoretical and practical implications from the findings are discussed.
\end{abstract}

Cite this article as: Onyango-Delewa, P. \& Nkote, I.N. (2019). "Budgetary Institutional Adjustments and Fiscal Discipline in Local Government: An Assessment of Entity Location Mediation", International Journal of Public Finance, 4(1), 1-22.

1 Lecturer, ORCID: 0000-0002-7770-6744, Gulu University, Faculty of Business and Development Studies, Uganda, ponydel2005@gmail.com

2 Senior Lecturer, ORCID: 0000-0001-6485-0205, Makerere University Business School, Dean Faculty of Commerce, Uganda, inkote@mubs.ac.ug 


\section{Introduction}

The current dynamics in the fiscal federalism environment perpetuated by increased demand for accountability and transparency, have generated enormous practice and research attention to local government (LG) fiscal discipline (Altunbas \& Tornton, 2012; Blom-Hansen, 1999; Von Hagen \& Harden, 1995). Thus, over the years, numerous public finance studies (e.g. Bahl \& Bird, 2008; Fjeldstad, 2006) have endeavored to create understandability of how local entities should run resourceallocation mechanisms that enhance fiscal discipline. To date, such empirical efforts have not yet been fully successful.

Fiscal discipline is an entity's ability to maintain its revenue, spending and borrowing structures at levels that are financially-sustainable and compatible with short and long-term objectives (Altunbas \& Tornton, 2012; Bahl \& Bird, 2008; BlomHansen, 1999). Under fiscal federalism, it is commonly argued that local governments should manage local economies through their own fiscal policies. The practice does not only augment regional stability but also reduces horizontal fiscal imbalances significantly. However, running autonomous fiscal policies is basically practical under viable fiscal discipline practices (Bahl \& Bird, 2008).

Achieving conventional standards of fiscal discipline in most local government jurisdictions remains largely illusionary. Numerous studies (e.g. Ebel \& Taliercio, 2005; Olowu, 2003; Poterba, 1994) attribute fiscal discipline setbacks in both developed and developing economies to adjustments frequently made in budgetary institutions. However, amending budgetary laws, statutes and regulations requires timely steps in order to effectively tailor fiscal operations to fiscal discipline standards (Ebel \& Taliercio, 2005).

Besides, Blom-Hansen (1999) and Fjeldstad (2006) observe that a local agency's geographical location is a fundamental factor in attaining sustainable fiscal discipline. Fjeldstad (2006) complements that the more distant the agency is from the central resource allocation unit, the lesser capacity it may in achieving fiscal discipline. This phenomenon is distinctive with strained and divergently resource-endowed local entities of various Sub-Sahara African economies (Fjeldstad, 2006; Olowu, 2003).

The foregoing views and largely inconclusive results of most empirical scholarships imply that a comprehensive understandability of the budgetary institutional adjustments-entity location-fiscal discipline triangulation is indispensable. This is specifically so if the current relentless LG fiscal discipline problem is to be effectively addressed. In the present study, fiscal discipline-related activities in 26 districts and other local governments in Uganda, East Africa are surveyed. Since the early 1990s when the country embraced decentralization as a political, administrative, fiscal resource-allocation policy, Uganda has been acclaimed for its fiscal federalism proficiency (Bahl \& Bird, 2008; Bird, 2011; Olowu, 2003).

The study is founded on two basic theoretical foundations. On one hand, it invokes fiscal illusion theory proposed by Krogstrup \& Wyplosz (2006) and Winer 
(1980). The theory posits that various fiscal discipline identities such as accountability and service delivery influence adjustments in budgetary institutions.

On the other hand, the formative fiscal federalism theory (Bradford \& Oates, 1971; Tiebout, 1956) was also engaged in order to explain budgetary institutional adjustments-entity location linkages and how they affect fiscal discipline.

Essentially, we offer two key contributions to the local government fiscal discipline knowledge body. First, we contribute to the fiscal discipline literature by providing a comprehensive conceptual framework (Bahl \& Bird, 2008; Von Hagen \& Harden, 1995) capable of explaining the budgetary institutions-entity location-fiscal discipline relationships.

Much as the need to examine such connectivity has been enunciated in previous research (Altunbas \& Tornton, 2012; Fjeldstad, 2006), such a model had never been adopted before. The oversight has over the years annulled comprehensive appreciation of fiscal discipline especially in the African setting (Bahl \& Bird, 2008; Bird, 2011; Olowu, 2003). Besides, drawing on the fiscal illusion and fiscal federalism theoretical (Tiebout, 1956; Winer, 1980) perspectives, this research benefits further understandability of LG fiscal discipline in conceptual terms.

Second, as previous research on LG fiscal discipline has been largely inconclusive and even portraying mixed results, proposing a direct and simplified model provides quite a balanced picture of the problem. Notable statistical methodologies such as: regression analysis (Simonton, 2003) and structural equation modeling-based path analysis and bootstrapping (Beran \& Srivastava, 1985; Marsh, Hau \& Wen, 2004; Preacher, Zyphur \& Zhang, 2010) are employed in order to comprehensively test the fiscal discipline paradoxical mechanisms.

The suggested and empirically-examined mechanisms are likely to fill an important gap in the fiscal discipline literature both in conceptual and empirical terms. Moreover, unveiling budgetary institutional adjustments-entity location context provides a more nuanced relational insight and potential explanation of the fiscal discipline dimension. The model presented as Figure 1 is proceeded by the study hypotheses developed in the subsequent section.

Figure 1: Conceptual Model

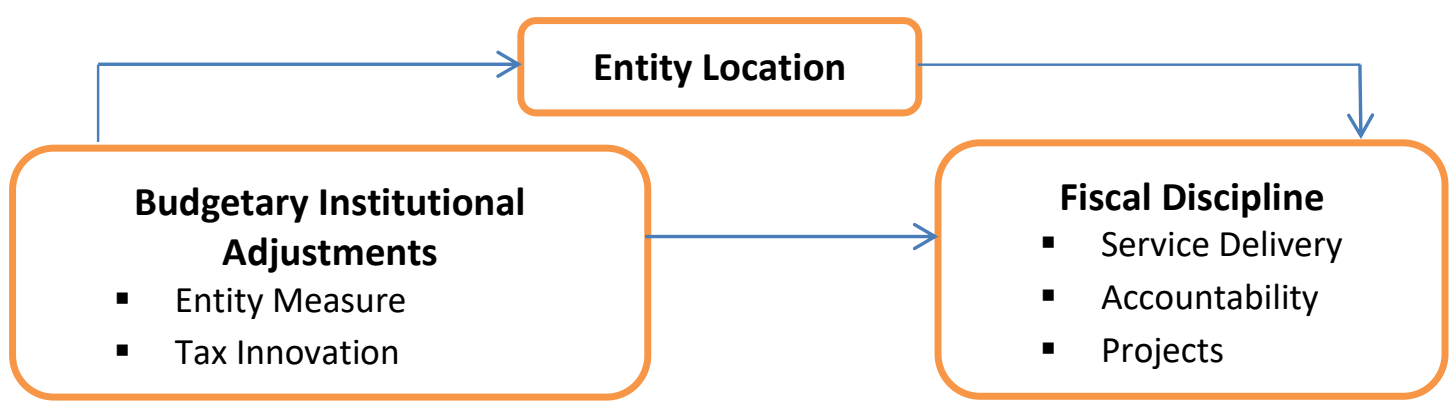

Source: Authors' elaboration. 


\section{Hypothesis Development}

\subsection{Fiscal Discipline}

In local government (LG), fiscal discipline is defined in terms of how the entity manages its gross revenue, spending, deficits, and debt in a given period of time. Technically, these four budget aggregates often considered constraints, are the key measures of its fiscal performance (Altunbas \& Tornton, 2012; Blom-Hansen, 1999). Thus, fiscal discipline abounds when one set of budget constraint is accompanied by another set of constraint. For instance, the LG enjoys fiscal discipline by achieving some deficit target. This is possible if borrowing is increased and spending restrained, say, amidst constrained revenue (Altunbas \& Tornton, 2012; Bahl \& Bird, 2008).

However, most localities attain such controls in situations where high spending often culminates into large budget deficits and more debt and tax burdens. Von Hagen \& Harden (1995) associate deficits-debt-tax burdens cohabitation with resourceconstrained entities of the developing world. The cohabitation is considered desirable in that it makes policymakers pay due attention to tax systems, expenditure program efficiency, and requirements for budgetary institutional adjustments (Bahl \& Bird, 2008; Von Hagen \& Harden, 1995).

Tax systems, expenditure program efficiency, and budgetary institutional adjustments are important ingredients of ideal resource allocation, growth, and service delivery structures (Bird, 2011).

Moreover, fiscal discipline allows entities to accommodate potential fiscal pressures such as unfunded public pension and contingent liabilities more conveniently (Altunbas \& Tornton, 2012). The entity is deemed fiscally disciplined if its budget aggregates are sustainably affordable from both ex-ante and ex-post contexts. Affordability relates to how the level and distribution of revenue, spending, and borrowing affect entity financial health both in the short and long-run (Altunbas \& Tornton, 2012; Von Hagen \& Harden, 1995).

Thus, in order to properly understand the comprehensive process of fiscal discipline, its constructs and thus affordability measurements (conceptualized in Figure 1): service delivery quality, accountability and transparency capacity, and ability to complete public projects need to be investigated more deeply.

\subsubsection{Service Delivery}

In their work on fiscal illusion theory, Bradford \& Oates (1971) and Winer (1980) underscored service delivery as a notable indicator of fiscal discipline especially in sub-national entities. Subsequent studies (Alesina et al., 1999; Fjeldstad, 2006; Poterba, 1994) interpret that perspective to imply that service delivery is both the quantity and quality of public goods and services local communities receive as a result of fiscal discipline practices. From the African-based local entities context, basic goods and services comprise agriculture, education, health, road network, and water and 
sanitation (Fjeldstad, 2006; Olowu, 2003). Since such services involve outlay of large amounts of resources and are often rendered in form of government projects, they significantly impact entity revenue, expenditure and debt.

In most African countries, local governments are barred from borrowing directly from either from local or foreign financial institutions and governments. According to Fjeldstad (2006) and Olowu (2003), such deterrence helps circumvent national macroeconomic disequilibrium and horizontal fiscal imbalances. Thus, local entities are largely funded by inter-governmental fiscal transfers and donor aid (Alesina et al., 1999; Fjeldstad, 2006).

Furthermore, service delivery in local government introduces yet another critical budgetary dimension, the budget deficit. Even in acclaimed fiscal federalism nations such as Ethiopia, Ghana, South Africa and Uganda majority local entities lack competent technical capacity.

Accordingly, they rarely balance the revenue-expenditure-deficit equation indicative of a standardized fiscal discipline mechanism (Alesina et al., 1999; Bahl \& Bird, 2008; Olowu, 2003).

The ability to effectively control fiscal balances is an internal decision-making process. Exacerbated by the common pool problem (Alesina \& Perotti, 1996), spending in such decentralized jurisdictions often exceeds their revenue-generation ability. The resultant budgetary strains persistently compromise fiscal discipline and consequently quality of service delivery. The situation is, however, addressed through bail-outs in form of inter-governmental fiscal transfers.

\subsubsection{Accountability and Transparency}

Achieving fiscal accountability and transparency in local government is a multifaceted mechanism and one often dictated by individual entity operational complexity (Ebel \& Taliercio, 2005). Commonly, fiscal accountability and transparency explains: medium-term fiscal policy and targets, fiscal aggregates risks, revenue and expenditure projections models and related assumptions, budget comprehensiveness, entity assets and liabilities, and budgetary information credibility (Altunbas \& Tornton, 2012; Ebel \& Taliercio, 2005; Von Hagen \& Harden, 1995).

According to Altunbas \& Tornton (2012), publicized medium-term revenue targets and expectations, spending projections and funding requirements enhance fiscal credibility. In effect, fiscal discipline is impacted and borrowing costs are minimized. Essentially, such publicity also creates an efficient local planning integrated framework. The framework facilitates the entity's engagement of fiscal projections and targets (Altunbas \& Tornton, 2012; Ebel \& Taliercio, 2005).

Local government stakeholders including central government and the donor community expect openness on fiscal aggregate-related risks. Such risks include those related to local revenue collection, utilities accessibility, and borrowing interest rates. 
When the risks are not catered for in advance, they seriously undermine fiscal planning and discipline (Ebel \& Taliercio, 2005).

During the budgetary process, local entities develop several models and adopt various assumptions in order to project revenue and expenditure. Much as most models and assumptions tend to be technical in nature, they should be simplified to enhance higher levels of government and the local community scrutiny. Accountability and transparency are also expected on the various budget components (Von Hagen \& Harden, 1995). For instance, the entity budget and balance sheet (statement of financial position) framework must clearly highlight all revenue sources, expenditure items, and liabilities. Such openness is also expected on arm's length agencies and other off-budget instruments for budget credibility purposes (Altunbas \& Tornton, 2012; Ebel \& Taliercio, 2005).

Finally, fiscal discipline involves candidness on the entity's assets and liabilities. All cash flows and fixed assets movements including current debts, current liabilities, arrears and contingent liabilities must be publicized. Ebel \& Taliercio (2005) assert that when past and planned fiscal operations are disclosed, it makes most entities reluctant to circumvent constraints on main budget operations by creating off-budget operations. Off-budget operations promote rent-seeking practices such as misappropriation of funds (Ebel \& Taliercio, 2005; Von Hagen \& Harden, 1995).

\subsubsection{Projects Completion}

The essence of decentralization and particularly fiscal federalism is to empower sub-national entities provide public goods and services to their local communities in the most effective manner (Bahl \& Bird, 2008; Olowu, 2003). Thus entities must participate in construction and setting-up of schools, health centers, roads, and drilling of boreholes. These projects involve large fiscal outflows commonly funded through inter-governmental fiscal transfers (grants) and bank loans, and sometimes by donor support.

Completing such projects in an accountable and transparent manner portrays some level of fiscal discipline (Fjeldstad, 2006). However, projects in most local entities especially in corruption-ridden African jurisdictions are rarely completed due to rampant fiscal deficits and bail-outs from central government. Commonly, bail-outs are seldom granted because of poor accountability and budget violations Bahl \& Bird, 2008; Olowu, 2003).

In sum, attaining fiscal discipline is quite a big challenge to majority local authorities. While some scholars (e.g. Rodden, 2002; Yilmaz \& Serrano-Berthet, 2010) attribute it to leadership capacity and partisan politics, adjustments in budgetary institutions seems to dominate the debate. Moreover, it is also stressed that entity geographical location is a crucial factor in its ability to attain sustainable fiscal discipline (Blom-Hansen, 1999; Fjeldstad, 2006). This case closely relates to horizontal fiscal imbalances commonly associated with local resource-endowment divergences. 


\subsection{Budgetary Institutional Adjustments}

As a potential predictor to local government fiscal discipline, budgetary institutional adjustments refer to those systematic amendments made to the rules and regulations that govern the way budgets are drafted, approved and implemented (Alesina \& Perotti, 1996; Ebel \& Taliercio, 2005). Typically, the amendments are reactions to anticipated fiscal shocks within the entity bureaucracy pertaining to, say, eminent budget deficits.

The World Bank Institute's governance initiative of the Poverty Reduction and Economic Reform Division (WBIPR), for instance, recommends that parliaments and local authorities adopt appropriate budgetary adjustments as a budget oversight mechanism (Alesina et al., 1999). Such action does not only strengthen fiscal accountability and transparency but also significantly curbs corruption.

In practice, however, local authority budgetary governance mandates have often been subdued by executive predominance and own technical deficiencies rendering them largely dysfunctional.

Alesina et al. (1999) and Yilmaz and Serrano-Berthet (2010) associate conducive fiscal discipline in local government with three major institutional arrangements. These are laws that create ex-ante constraints on budget deficits, hierarchical (top-bottom) procedural rules, and transparent procedures. Laws that establish ex-ante constraints on budget deficits are simply restrictions of numerical nature designed to limit excessive budget deficits. Such deficits emanate from entity borrowings (debt) and practices where expenditure persistently exceeds revenue (Yilmaz \& Serrano-Berthet, 2010).

Hierarchical procedural rules are legislative mandatory rules that entities must follow in the budget-making and implementation process. Such institutions limit legislature capacity to amend the executive proposed budgets haphazardly (Rodden, 2002; Von Hagen \& Harden, 1994). The institutions are prevalent in situations where executive veto on legislative amendment proposals tends to neutralize or at least diminish local authority amendment powers. Transparency procedures pertain to transparency in respect to budgetary and fiscal information.

Other budgetary institutional structures that localities and the executive can adjust to bring about fiscal discipline include: two-stage budgeting undertaken prior to setting of anticipated budget deficit targets, restrictions on amendments of spending proposals, constitutional limits on deficit spending, debt ceilings and fiscal targets (Yilmaz \& Serrano-Berthet, 2010).

Previous research (Blom-Hansen, 1999; Fjeldstad, 2006) suggests that at any time within the budgetary period, national executive and local jurisdictions can adjust one or a combination of the various budgetary institutions in a bid to attain targeted fiscal discipline levels. This empirical observation supports the common pool problem (Von Hagen \& Harden, 1994) stand and fiscal illusion theory (Winer, 1980) view that local budgetary institutional adjustments are feasible in respect to entity measure, tax innovations, and grants structure. 


\subsubsection{Entity Measure}

A broad body of research (Altunbas \& Tornton, 2012; Blom-Hansen, 1999; Ebel \& Taliercio, 2005) associates local government (LG) fiscal discipline in developing countries with numerous factors. These include: budgetary institutional framework, central government patronage, and community cooperation. However, entity measure; the numerical number of local governments a country runs in a particular budget year is fundamental (Blom-Hansen, 1999; Ebel \& Taliercio, 2005).

The more LGs the country operates, the more complicated it becomes to achieve optimal budgetary governance at both national and locality levels. The complications arise from identifying ideal budget decision actors, gauging actor interests and incentives, and deciphering both formal and informal institutions that shape inter-entity interactions (Ebel \& Taliercio, 2005).

According to the country's Local Government Act (1997 amended), local governments in Uganda include city (Kampala), districts, municipalities, and subcounties. Currently, the country is a host to one city, 122 districts, 30 municipalities and and over 1,000 sub-counties. These localities are scattered in seven geographical regions: western, northern, north-eastern, eastern, central, south-western, and western (Ministry of Local Government, 2017).

Consistent with past research (e.g. Bird, 2011; Ebel \& Taliercio, 2005), creation of more localities in Uganda has not only led to power capture by the few elites, but has extensively sidelined local people from the policy-making process and consequently compromised social services provision. Other rent-seeking practices such as corruption are also rampant (Bird, 2011).

Therefore based on the foregoing entity measure-fiscal discipline discussion, it is proposed:

Hypothesis 1: Entity measure positively contributes to fiscal discipline in local government.

\subsubsection{Tax Innovation}

Fragmentation of a political system into numerous regional local entities often culminates into uncoordinated tax-related decisions (Bahl \& Bird, 2008; Bird, 2011; Ebel \& Taliercio, 2005). Such decisions rarely exploit relevant economies of scale related to public services application and inefficient costly public infrastructure. According to Ebel \& Taliercio (2005), this signifies a potential fiscal discipline threat.

Furthermore, Bahl \& Bird (2008) and Bird (2011) noted that local authorities find themselves in a regional competition for existing tax types. The consequence of such competition for favorable tax rates often truncates government revenue.

When public services remain persistently stagnant, the temptation is debt financing as the only viable alternative. In order to avoid tax-debt migration, fiscal illusion theory (Krogstrup \& Wyplosz, 2006; Winer, 1980) recommends that local 
authorities adopt appropriate tax innovations. Common and practical tax innovations in income-strained local entities comprise introducing new tax types and making adjustments in existing tax rates. This is, however, feasible after carefully studying community income levels and potential reaction. Besides, the innovations must not jeopardize national macroeconomic policy and budgetary framework nor perpetuate horizontal fiscal imbalances (Bahl \& Bird, 2008; Ebel \& Taliercio, 2005).

In Sub-Saharan Africa countries, Uganda inclusive, property tax levied on local buildings is the most paying source of local revenue. Others include various types of fees, market dues, surcharges, and penalties (Fjeldstad, 2006; Olowu, 2003; Rodden, 2002). Local entity fiscal discipline is therefore measured by how effective local revenues, central government grants and donor aid are managed.

Much as the assessment augments quality service delivery on an accountable and transparent basis and avoids supplementary budgeting, few LGs in the country meet this standard. Tax innovations in majority entities are constrained by poverty, low incomes, political interference, and entity measure (Fjeldstad, 2006; Rodden, 2002). Thus, we propose:

\section{relationship.}

Hypothesis 2: Tax innovations and fiscal discipline have a positive

\subsubsection{Grant Structure}

The local community, suppliers, creditors and other principle local entity stakeholders are likely to recognize entity obligations as sovereign; akin to those of central government. This is more especially if the obligations happen to be financed purely by local taxes, fees, charges, and borrowing. Thus, fiscal deficits, fiscal imbalances (both vertical and horizontal), and bail-out concerns would be irrelevant and irrational (Alesina et al., 1999; Yilmaz \& Serrano-Berthet, 2010). Moreover, other scholars (e.g. Altunbas \& Tornton, 2012; Porteba 1994; Rodden, 2002) are of the opinion that the absence of such irregularities in local government fiscal structures significantly enhance policy-driven fiscal discipline.

In practice, however, local revenue lacks the capacity to sufficiently fund the numerous fiscal obligations faced by local governments in majority countries of the world. Commonly, the gap is therefore often filled by intergovernmental fiscal transfers (grants) and; in jurisdictions of majority Sub-Saharan Africa entities, by donor aid (Rodden, 2002; Yilmaz \& Serrano-Berthet, 2010). The fiscal illusion theory (Krogstrup \& Wyplosz, 2006) posits that intergovernmental grants constitute that vertical flow of funds that takes place between governments. That funds-transition is initiated by central government from a national common pool; the consolidated fund, and granted to sub-national entities (Krogstrup \& Wyplosz, 2006; Bird, 2011).

The transfers take three dominant forms; conditional, unconditional, and equalization grants. Conditional grants are meant to finance development-oriented projects related to agriculture, education, health, road network, and water and 
sanitation. Given their large investment resource characteristics, conditional grants are normally managed by local authorities but under rigorous central government patronage and oversight (Altunbas \& Tornton, 2012).

Local government autonomy in respect to conditional grants is therefore highly compromised. In Africa, fiscal autonomy in regard to such grants is restricted on the basis of unreliable budget and financial management technical capacity, corruption, and likely partisan politics influences. Unconditional and equalization grants benefit local entity expenditure obligations with somehow relaxed autonomy. The two types of grants are meant to finance recurrent spending and activities designed to address horizontal fiscal imbalances respectively (Altunbas \& Tornton, 2012; Rodden, 2002).

From the fiscal discipline and fly paper effect contexts, recent fiscal federalism literature (Blom-Hansen, 1999; Von Hagen \& Harden, 1995; Yilmaz \& Serrano-Berthet, 2010) observes that intergovernmental fiscal transfers rarely breed meaningful reductions in local taxes. Besides, increases in the transfers instead often stimulate local spending than would be expected if local revenue collections increased. This is consistent with the public economy theoretical and empirical studies view (Alesina \& Perotti, 1996; Bradford \& Oates, 1971) that majority individuals consider grants "ownrevenue" but camouflaged by fiscal policy and politics.

The "own-revenue" perception exacerbated by central government stringent grant control and patronage does not only compromise sub-national fiscal accountability and transparency but heavily undermines management commitment. The ultimate outcome is an undercut in entity fiscal discipline goal.

Considering the foregoing analytical views, the following hypothesis is therefore proposed:

Hypothesis 3: Grant structure has a positive relationship with fiscal discipline.

\subsection{Entity Location: Mediation Consideration}

A number of fiscal discipline studies (e.g. Bahl \& Bird, 2008; Blom-Hansen, 1999; Fjeldstad, 2006) have recently demonstrated that a local government's geographical location from the center is a pivotal factor in attaining its fiscal discipline endeavors. In Sub-Saharan Africa and specifically Uganda, public resource allocation is formula-driven.

Key considerations include: entity population size, previous budgets performance and accountability record, available resource quantity, and geographical location (Bird, 2011; Olowu, 2003; Yilmaz \& Serrano-Berthet, 2010).

Entity location is critical in that the more distant an entity is from the center, the less the opportunity it may have in identifying and engaging accountable technical manpower (Blom-Hansen, 1999; Fjeldstad, 2006). Such units are also not easy to access due to lack of basic infrastructure like roads and electric power and thus operate manual accounting systems. Besides, their local communities are largely poor 
and illiterate and barely appreciate the relevancy of effective budgeting, budgetary institutionalization, fiscal discipline, and accountability (Fjeldstad, 2006).

In their seminal work, Olowu (2003) and Yilmaz and Serrano-Berthet (2010) indicated that resource-endowment differences in majority rural-based local entities in African often generate horizontal fiscal imbalances. These imbalances are normally beyond the fiscal capacity of equalization grants periodically allocated to local entities. This explains why supplementary budgeting (fiscal incrementalism) and bail-out practices; serious fiscal discipline setbacks, dominate entity operations. In Uganda, several local governments admit their inability to contain bail-out-fiscal discipline complications and frequently look at central government for rescue (Fjeldstad, 2006; Olowu, 2003; Von Hagen \& Harden, 1995). We therefore propose that:

Hypothesis 4: Entity location mediates budgetary institutional adjustmentsfiscal discipline relationship.

\section{Methods}

\subsection{Sampling}

As noted earlier, Uganda is currently comprised of seven regions; western, south-western, central, north-western, northern, north-eastern, and eastern regions. In order to advance the country's political and administrative but particularly fiscal federalism agenda, the regions are divided into one city (Kampala), 122 districts, 30 municipalities and 1,500 sub-counties (Ministry of Local Government, 2017).

This research was conducted in four purposively-selected (Baruch \& Holtom, 2008) regions of north-western, northern, north-eastern, and eastern. The regions (a host to 33 districts, 12 municipalities, and about 400 sub-counties), were selected on the basis of consistently reported expenditure governance pitfalls (Fjeldstad, 2006; Ministry of Local Government, 2017; Olowu, 2003; Von Hagen \& Harden, 1995). Target districts and municipalities were chosen on a purely-random basis but sub-counties were also purposively identified given their large numbers.

At district level (unit of analysis), participants included: principal administrators (Chief Administrative officer; Resident District Commissioner; Local Council Five Chairperson), Chief Finance Officer, Department Heads, and finance function employees. At municipality and sub-county levels, Town Clerks, Treasurers, SubCounty Chiefs, accountants and their finance staff participated in the survey.

Through pure-random and purposive sampling procedures (Scandura \& Williams, 2000), a total sample of $n=243$ participants was generated. In gender terms, $58 \%$ (141) of the subjects were male and $42 \%$ (102) female. Their mean age was 41 years $(S D=1.264)$ with job mean tenure of 4 years $(S D=1.617)$. It was also found that $52 \%$ of the participants were married, $34 \%$ single and $14 \%$ widowed. Altogether, $33 \%$ held first degree certificates, $39 \%$ held diplomas, and $28 \%$ were secondary school 
drop-outs. The sample consisted of $31 \%$ finance activity-based employees, $18 \%$ administrators and CFOs, $40 \%$ heads of department, and $11 \%$ civic leaders.

From the local entity expenditure governance context, the current study's biographical data seem to suggest that the investigated entities operate more or less a gender-balanced mechanism. Consistent with previous research (Bird, 2011; Olowu, 2003), most of their personnel are middle-aged, fairly educated, and hold family responsibilities. Moreover, the majority have served for short periods with potential to support LGs for a long time in future.

\section{Measures}

\subsection{Service Delivery}

This construct was measured by 15 items related to those in validated scale versions (Altunbas \& Tornton, 2012). A sample item: "[...] the nature of services rendered is fair", revealed a Cronbach's $(\alpha=0.842)$ level of reliability.

\subsection{Accountability}

In order to assess accountability under public expenditure governance, 12 items related to modified scales in (Blom-Hansen, 1999; Von Hagen \& Harden, 1995) were used. Sample item: "[...] accountability is not relevant for effective outlay control" exhibited ( $\alpha=0.817)$ reliability.

\subsection{Projects Completion}

Project completion was measured by 12 items drawn from the scales in (Bahl \& Bird, 2008). Sample item: "[...] facilitates prompt project accomplishment" exhibited an $(\alpha=0.794)$ internal consistence.

\subsection{Entity Measure}

Based on 13 items closely related to those in scales from (Ebel \& Taliercio, $2005)$, the influence of entity measure on LG fiscal discipline was tested. A sample item: "[...] is pivotal to entity fiscal discipline" exhibited an $(\alpha=0.885)$ reliability level.

\subsection{Tax Innovation}

The construct tax innovation was evaluated by 12 items ( $\alpha=0.816$ ) as in validated scales in the work of Alesina \& Perotti (1996) and Bird (2011). Sample items: "When relevant, this LG introduces new taxes."; "[...] community is often tax inverse." 


\subsection{Grant Structure}

Designed along validated scales in Alesina et al. (1999), Olowu (2003) and Poterba (1994), some 13 items were adopted to assess grant structure in local entities. The items; with a sample statement: "[...] grant amounts are often sufficient", exhibited Cronbach coefficient $(\alpha=0.863)$.

\subsection{Entity Location}

Apparent Budgetary Institutional Adjustments-Fiscal Discipline relationship mediator, entity location, was measured by 11 items composed similar to scales in (Blom-Hansen, 1999; Fjeldstad, 2006). Sample item: "[...] location is not important for fiscal discipline", all displayed ( $\alpha=0.798$ ) internal consistency.

The preceding construct measures indicate that their respective study variables hold internal consistence (reliability) levels $(0.68<\alpha<0.94)$ generally accepted in statistical circles (Marsh et al., 2004; Simonton, 2003).

\section{Control Variables}

Six participant demographic characteristics; gender, age, marital status, educational level, position held, and tenure were adopted as control variables. Previous studies (e.g. Ebel \& Taliercio, 2005; Krogstrup \& Wyplosz, 2006) suggest that biographical variables often relate with fiscal discipline in local government. Thus, [Gender: ( $0=$ female, $n=102 ; 1=$ male, $n=141)$ ]; [Age in years: $(1=20-30, n=34 ; 2=31-40$, $n=128 ; 3=41+, n=81$ )]; [Marital status: ( $1=$ single, $n=59 ; 2=$ married, $n=116 ; 3=$ others $n=68)$ ]; [Educational level: (1=certificate, $n=21 ; 2=$ diploma, $n=64 ; 3=$ bachelor's degree+, $n=158)$ ]; [Job tenure in years: $(1=1-3, n=67 ; 2=4-6, n=118 ; 3=7+, n=58)$ ] were controlled for.

Additionally, a latent factor adopted to enhance instrument validity verification and subjected to Harman's Single Factor approach-based confirmatory factor analysis (CFA), was controlled for. This was to minimize possible repressive effect CFA latent factors tend to have on hypothesis results (Beran \& Srivastava, 1985).

\section{Analytical Approach}

By engaging SPSS software, the various study variables and their constructs were first tested for relative association (correlation) and prediction (regression). Thereafter, as in previous studies (Marsh et al., 2004; Scandura \& Williams, 2000; Simonton, 2003), other statistical attributes such as means, standard deviations, reliability (internal consistence), validity, and multi-collinearity were established.

The study hypotheses (both direct effect and indirect effect) were tested by means of structural equation modelling (SEM) using the Analysis of Moments Structures (AMOS) computerized package (Bollen \& Stine, 1992; Preacher, Zyphur \& 
Zhang, 2010). On the basis of a two-step strategy, SEM helps to verify whether variables in hypothesized models are consistent with original data structure.

In step one, a measurement model is tested using confirmatory factor analysis but without involving any control variable (Preacher et al., 2010). The idea is to generate output from control variable latent construct items of a higher-order-term. The output is required in constructing effective model goodness-of-fit indices and testing for direct and indirect (mediation) effects related to various study variables (Bollen \& Stine, 1992; Preacher et al., 2010).

In step two, the target structural model is anticipated to exhibit mediation estimation statistics being sought for. Marsh et al. (1992) recommend that where only one item is exhibited for each of the control variable latent constructs error variances, all the variances should be fixed at zero value. Thus, in order to observe that condition, the current study's control variable latent constructs and their model paths were loaded on both its mediating variable (entity location) and the dependent variable (fiscal discipline) (Preacher et al., 2010).

\section{Results}

\subsection{Descriptive Statistics and Correlation Analysis}

Correlation coefficients including means, standard deviations, and reliability ratings for the target model variables and their constructs are reported in Table 1. All measures exhibit high internal consistence reliabilities, with $(\alpha)$ ranging from (0.75) to (0.85). The dependent variable (fiscal discipline) portrayed the lowest mean value (2.92), but its construct (accountability), the highest (3.11). Fiscal discipline standard deviation (SD) value was the highest (1.607) while one of its constructs (project completion) showed lowest SD (1.497). However, all item mean and SD values were quite fair and in the right direction (Baruch \& Holtom, 2008; Simonton, 2003).

Furthermore, correlation coefficients ranged from $(-0.147)$ to $(0.442)$ and were statistically significant at both (0.01) and (0.05) levels, 2-tail measurement. Most of them exhibited a pattern consistent with proposed hypotheses of the study. For instance, budget institutional adjustments hold a significant but negative relationship with entity fiscal discipline

$(r=-0.342, p<0.05)$. This suggests that positive adjustments made in budget institutions impair fiscal discipline efforts.

On the contrary, entity location-fiscal discipline relationship $(r=0.257, p<0.01)$ indicates that entity's location directly affects how it executes its fiscal discipline. Likewise, its location also directly affects the nature of budget institutional adjustments it makes in a particular period. This is indicated in the output $(r=0.442, p$ $<0.01)$. 
Onyango-Delewa, P. \& Nkote, I. N. (2019). "Budgetary Institutional Adjustments and Fiscal Discipline in Local Government: ...", International Journal of Public Finance, 4(1), 1-22.

Table 1: Variable Means, Standard Deviations, Reliability Coefficients, and Correlations

\begin{tabular}{|c|c|c|c|c|c|c|c|c|c|c|c|}
\hline Variable & $M$ & SD & 1 & 2 & 3 & 4 & 5 & 6 & 7 & 8 & 9 \\
\hline 1. ServDelivery & 3.06 & 1.517 & .826 & & & & & & & & \\
\hline 2. Accountability & 3.11 & 1.552 & $-.340^{*}$ & .871 & & & & & & & \\
\hline 3. ProjctCompltn & 3.03 & 1.497 & -.254 & $.321^{* *}$ & .794 & & & & & & \\
\hline 4. FD & 2.92 & 1.607 & $.188^{* *}$ & $.289^{*}$ & $.285^{* *}$ & .843 & & & & & \\
\hline 5. EntityMeasur & 2.97 & 1.551 & -.276 & .144 & $.278^{*}$ & $-.375^{* *}$ & .816 & & & & \\
\hline 6. TaxInnovatn & 3.13 & 1.529 & $-.252^{\star}$ & $-433^{*}$ & $.137^{\star}$ & $-.240^{* *}$ & $-.235^{\star \star}$ & .839 & & & \\
\hline 7. GrantMgmt & 2.95 & 1.530 & $.414^{*}$ & .282 & $-.168^{* *}$ & .122 & $-.147^{*}$ & $-.249^{* *}$ & .768 & & \\
\hline 8. BIA & 3.07 & 1.538 & $-.353^{* *}$ & $-.314^{*}$ & $-.427^{*}$ & $-.342^{\star}$ & -.023 & -.060 & $-.376^{* \star}$ & .825 & \\
\hline 9. EL & 3.05 & 1.526 & $.236^{*}$ & $-.255^{*}$ & $.182^{\star *}$ & $.257^{\star *}$ & .008 & .121 & .232 & $.442^{* *}$ & .837 \\
\hline
\end{tabular}

Source: Authors' elaboration.

Notes: $n=243$; ServDelivery $=$ Service Delivery; ProjctCompltn = Project Completion; FD = Fiscal Discipline; EntityMeasure = Entity Measure; TaxInnovatn = Tax Innovation; GrantMgmt = Grant Management; BIA = Budgetary Institutionalization Adjustments; EL = Entity Location; Reliability alpha coefficients in parentheses; ${ }^{* *}$ Correlation is significant at the 0.01 level (2-tailed); * Correlation is significant at the 0.05 level (2-tailed).

\section{Hypotheses Testing}

As indicated in the preceding section, study hypotheses were tested on a bimodel (measurement and structural) basis. Supported by five latent items, confirmatory factor analysis (CFA) results from the measurement model showed quite significant item loadings and reasonable goodness-of-fit indices. The results support structural equation modelling testing (Marsh et al., 2004): (Range: [0.43 - 0.97], $p<$ $0.01 ; \chi 2=967.53, \mathrm{df}=13, \mathrm{p}<0.01 ; \mathrm{CFI}=0.98 ; \mathrm{NNFI}=0.97 ; \mathrm{RMSEA}=0.02 ;$ SRMR $=$ $0.06)$.

Besides, CFA was also performed on the Harman's One Factor model to test for the common methods threat to the study dataset. The model's relatively weak indices: $[X 2=15.471 ; \mathrm{df}=18 ; \mathrm{X} 2 / \mathrm{df}=0.860 ; \mathrm{IFI}=0.784 ; \mathrm{TLI}=0.898 ; \mathrm{CFI}=0.901 ; \mathrm{RMSEA}=0.101$ (L.090, H.112)] indicated that data were free from that threat (Marsh et al., 2004; Preacher et al., 2010).

Statistical results displayed in Tables 1 and 2 further suggest that the study variables and majority of their constructs portray strong reliability coefficients and significant factor loadings $(\beta>0.50, p<0.01 ; \alpha \geq 0.700)$. Coupled with minimal common methods variance threat, Marsh et al. (2004) associate such output with a robust and quite reliable study instrument's construct and discriminate validity.

In phase two, a structural model was developed to facilitate structural equation modelling (SEM) (Bollen \& Stine, 1992; Marsh et al., 2004). However, in order to avoid compromising SEM test results, the study variables had to be first evaluated for possible multi-collinearity linkages. Conventionally, absence of the multi-collinearity threat is established by tolerance values (TVs) and variance inflation factors (VIFs) items that depict $[(<1.00) ;(<10.0)]$ status respectively (Marsh et al., 2004). Table 2 (TVs) and (VIFs) output confirm that position. 
Notable simulation research (e.g. Beran \& Srivastava, 1985; Preacher et al., 2010) asserts that structural models with strong goodness-of-fit indices must be adopted if study hypotheses' direct and indirect effects have to be measured effectively. Thus, we engaged the model with indices: Chi-Square $(\chi 2)=1.437 ; \mathrm{df}=1$; $\mathrm{p}=.231 ;(\mathrm{X} / \mathrm{df})=1.437 ; \mathrm{GFI}=.988 ; \mathrm{NFI}=.988 ; \mathrm{RFI}=.884 ; \mathrm{IFI}=.996 ; \mathrm{TLI}=.962 ; \mathrm{CFI}=.996$; RMSEA $=.043($ L.000; H.186) at 90 , to test the effects.

Table 2: Multiple Regression Coefficients and Structural Equation Modeling

\begin{tabular}{|c|c|c|c|c|c|c|c|c|c|}
\hline \multirow[t]{8}{*}{ HYP } & \multirow[t]{2}{*}{ Model } & \multicolumn{2}{|c|}{$\begin{array}{l}\text { Unstandardized } \\
\text { Coefficients }\end{array}$} & \multirow{2}{*}{$\begin{array}{c}\begin{array}{l}\text { Standardized } \\
\text { Coefficients }\end{array} \\
\beta\end{array}$} & \multirow[t]{2}{*}{$\begin{array}{c}\text { CR } \\
\text { (t-value) }\end{array}$} & \multirow[t]{2}{*}{ Sig. } & \multicolumn{2}{|c|}{$\begin{array}{l}\text { Collinearity } \\
\text { Statistics }\end{array}$} & \multirow[t]{2}{*}{$\begin{array}{c}95 \% \\
\mathrm{Cl}\end{array}$} \\
\hline & & $\bar{\beta}$ & SE & & & & TV & VIF & \\
\hline & Constant & 8.263 & 1.421 & - & 5.813 & $.000^{*}$ & - & - & \\
\hline & Em & 1.015 & .236 & .830 & 4.303 & $.001^{* *}$ & .816 & 1.225 & \\
\hline & Txi & .361 & .215 & .610 & 1.676 & $.116^{*}$ & .885 & 1.129 & \\
\hline & Gmt & .303 & .205 & .587 & 1.480 & $.161^{* *}$ & .809 & 1.236 & \\
\hline & $\mathrm{R}^{2}$ & & & .574 & & & & & \\
\hline & Adj. $R^{2}$ & & & .483 & & & & & \\
\hline SEM & $\begin{array}{l}\text { Direct } \\
\text { Effects }\end{array}$ & & & & & & & & \\
\hline $\mathrm{H} 1:$ & FSD 4 & $\mathrm{Em}$ & & 773 & 1739 & $372^{* *}$ & & & \\
\hline H2: & FSD & - Txi & & .581 & 1.392 & $.122^{* *}$ & & & \\
\hline \multirow[t]{2}{*}{ H3: } & FSD $\leftarrow$ & $-G m t$ & & .662 & 1.629 & $.259^{*}$ & & & \\
\hline & $\begin{array}{l}\text { Indirect } \\
\text { Effect }\end{array}$ & & & & & & & & \\
\hline \multirow[t]{2}{*}{ H4: } & $\mathrm{BIA} \leftarrow$ & FSD & & -.647 & 1.293 & $.313^{* *}$ & & & \\
\hline & ELN & FSD & & -.521 & 1.386 & $.209^{* *}$ & & & {$[-.067 ; \quad .024]$} \\
\hline
\end{tabular}

Source: Authors' elaboration.

Notes: HYP=Hypothesis; $\mathrm{CR}=$ Critical Ratio; TV=Tolerance Value; VIF=Variance Inflation Factor; $\mathrm{Cl}=$ Confidence Interval; Em=Entity Measure; Txi=Tax Innovation; Gmt=Grants Management; FSD=Fiscal Discipline; BIA=Budgetary Institutional Adjustments; ELN=Entity Location; ${ }^{*} p<0.05 ;{ }^{*} p<0.01$; Hypotheses Status:H1 (Supported); H2 (Supported); H3 (Supported); H4 (Not Supported); BIA, ENL, and FSD are the study variables.

\subsection{Direct Effect Tests}

In Hypothesis 1, the study anticipated that in local government, entity measure holds a positive relationship with fiscal discipline. Both regression analysis $(\beta=.830, p<$ .01 , $t$-value 4.303$)$ and SEM $(\beta=.773, p<0.01$, $t$-value 1.739$)$ results (Table 2 ) indicate that data confirm that position. Hypothesis 2: tax innovation relates positively with fiscal discipline also received data backing as per regression analysis $(\beta=.610, p<.05, t$ value 1.676) and SEM $(\beta=.581, p<0.01, t$-value 1.392) results. Similarly, regression ( $\beta=.587, p<.01$, $t$-value 1.480)-SEM ( $\beta=.662, p<0.05$, t-value 1.629) output suggests that data support Hypothesis 3 proposition that grants management has a positive relationship with fiscal discipline in local entities. Further, the study regression model unveiled [(R2=.574; Adjusted R2=.483)] values. 


\subsection{Indirect (Mediation) Effect Test}

Conceptually, the method employed in testing mediation by SEM (Preacher et al., 2010) is more or less analogous to that in Baron and Kenny (1986) and Kenny, Kashy and Bolger (1998). In both approaches two models; 1 and 2, are considered. While model 1 is developed to hold the potential mediator; that is, entity location in the current study, model 2 is structured to suppress the mediator and enhance (predictor-criterion) relationship evaluation (Baron \& Kenny, 1986; Kenny et al., 1998; Preacher et al., 2010).

Mediation is considered present no matter the (predictor-criterion) relationship results status, but as long as the (predictor-mediator) and (mediator-criterion) relationships display statistical significance (Kenny et al., 1998; Preacher et al., 2010). The SEM-based mediation results are also presented in Table 2. Accordingly, the results; $[(\beta=-0.647, p<0.01, t$-value 1.293; $\beta=-0.521, p<0.01$, $t$-value 1.386$)]$, suggest that data did not support Hypothesis 4. This implies that the location of an entity does not have any bearing on the interaction between budgetary institutional adjustments it makes and its fiscal discipline status.

In order to confirm the SEM results further, data were subjected to bootstrap analysis as recommended in other simulation studies (e.g. Beran \& Srivastava, 1985; Bollen \& Stine, 1992).

Bootstrapping first involves generating indirect effect confidence intervals ( $\mathrm{Cls}$ ) by closely exploring the related model. The 2,500 replicated sub-samples exhibited a statistically-insignificant (0.10) entity location effect-size with $95 \%$ bias-corrected (Cls) [-0.067; 0.024] (Table 2). The effect is considered insignificant since its bias-corrected (Cls); [-0.067, 0.024], enclose a zero value therein (Hancock \& Nevitt, 2001; Preacher \& Hayes, 2008). These bootstrap results confirm that Hypothesis 4 was indeed not supported by data.

\section{Discussion}

\subsection{Study Contribution}

The results of the first three hypotheses of this study are quite important and add to the existing literature. However, the key contribution of the research is to budgetary institutional adjustments-entity location-fiscal discipline literature. Entity location was examined and indeed confirmed that it is not the mechanism through which budgetary institutional adjustments affect fiscal discipline in local government.

Altunbas \& Tornton (2012) describe fiscal discipline as that level of fiscal performance in which local entities are able to mobilize revenue and effectively manage expenditure and borrowing. When this capacity is executed through own fiscal policy initiative, it creates regional stability, minimizes horizontal fiscal imbalances, and promotes service delivery (Altunbas \& Tornton, 2012; Blom-Hansen, 1999). 
Additionally, it supports the earlier work of Von Hagen \& Harden (1995) which, inter alia, found that fiscal discipline is not only helpful for maintaining prudent deficit and debt levels, but enhances taxation and institutional compliance.

Adherence to various budgetary institutional adjustments is considered an important signal of fiscal accountability. The findings of the current study are also in congruence with empirical ideas expounded by Bahl \& Bird (2008) in which effective projects completion especially in resource-strained entities of Sub-Saharan Africa is emphasized. Thus, in sum, this investigation is a big contribution to the contextual mechanisms required for fiscal discipline in local government.

Furthermore, the research supports numerous findings of past empirical work which argue that there is need to pay attention to entity budgetary institutional adjustments (Alesina \& Perotti, 1996; Alesina et al., 1999; Bird, 2011; Ebel \& Taliercio, 2005; Olowu, 2003; Poterba, 1994). Consistent with Ebel \& Taliercio (2005) and Olowu (2003) observation that entity measure has serious bearing on fiscal discipline; this study reiterates the point that the number of local governments affects available resource package and thus its management.

Results of the current research further support the budgetary institutional adjustments -fiscal discipline linkages in local entities. Specifically, it proves that tax innovation is certainly a strong predictor of fiscal discipline as highlighted in the work of Alesina \& Perotti (1996) and recently Bird (2011). Adopting tax measures tailored to local community payment capacity does not only enhance tax collectivity but also significantly motivates taxpayers (Bird, 2011; Poterba, 1994).

The current results demonstrate that local entities in Sub-Saharan Africa in general and those of Uganda in particular heavily rely on grants (inter-governmental fiscal transfers) for budgetary survival. As indicated in previous studies (Alesina et al., 1999; Ebel \& Taliercio, 2005; Olowu, 2003), such entities must effectively manage available grant funding if they have to achieve required fiscal discipline. This finding is considered a noteworthy contribution to the existing literature especially in studies where grants have often been overlooked.

As indicated earlier, past scholarly work (e.g. Blom-Hansen, 1999; Fjeldstad, 2006) attribute successful fiscal discipline operations in local government to its geographical location. The more distant a locality is from the centre, the more funding it may receive as per most budget allocation formulas in Africa.

However, the findings from the current research contradict that previous empirical evidence. It offers support to the work of Bahl \& Bird (2008), Ebel \& Taliercio (2005), and Olowu (2003) which found that despite location-setting benefits, various rural-based localities still face fiscal discipline challenges. This is largely due to manpower deficiencies, poor budgetary control oversight, and corruption. In a nutshell, entity location is not necessarily a critical concern when formulating fiscal discipline policy. 


\section{Conclusion}

This research is an important contributor to fiscal discipline literature in regard to the management of public resources in general and those of local government in particular. It stands out as one of the few studies in which the three fiscal discipline constructs; service delivery, accountability, and projects completion, are examined in a single study. The constructs have often been ignored by past research.

The research demonstrates that fiscal discipline in local government is quite achievable even in resource-constrained and largely corrupt economies of the developing world like those in Sub-Saharan Africa, Uganda inclusive. In support of past empirical evidence (Alesina \& Perotti, 1996; Alesina et al., 1999; Bird, 2011; Ebel \& Taliercio, 2005; Olowu, 2003; Poterba, 1994), properly executed budget institutional adjustments can engender fiscal discipline. This is workable regardless of the entity location under review in the country's geographical set-up.

\section{Theoretical and Practical Implications}

Findings from the study impact local government fiscal discipline literature generally and theory specifically on several fronts. Firstly, the study promotes the theoretical position of the fiscal illusion theory (Krogstrup \& Wyplosz, 2006; Winer, 1980 ) by introducing new insights of how fiscal discipline attributes; service delivery, accountability, and projects completion can explicitly accommodate budget institutional adjustments to enhance fiscal discipline.

Initially, the theory did not take in-depth regard of potential influence of budget institutional adjustments in local entity fiscal discipline endeavours (Ebel \& Taliercio, 2005; Krogstrup \& Wyplosz, 2006).

Secondly, the fiscal federalism theory posits that strategically-tailored budget institutional adjustments can generate high profile fiscal governance in decentralized economies (Bradford \& Oates, 1971; Tiebout, 1956). By implication, that theoretical view suggests that fiscal discipline in local entities is actually feasible. The current research reinforces fiscal federalism theory by introducing the otherwise previously overlooked budget institutional adjustments constructs of entity measure, tax innovation, and grant structure into its theoretical framework. Consistent with past research (Ebel \& Taliercio, 2005; Olowu, 2003; Poterba, 1994), the study findings suggest that fiscal discipline in local government is easily attainable but if the entity measure-tax innovation-grant structure triangulation is effectually managed.

From a practical (managerial) standpoint, achieving acceptable fiscal discipline standards has important implications for local entity administrators, employees, and local community representatives. This research helps administrators and employees to understand fiscal discipline relevance to entity performance. Such knowledge reinforces the innovative capability of the entity. Its findings support the work of BlomHansen (1999) and Von Hagen \& Harden (1995) which states that local entity fiscal 
discipline does not only enhance fiscal performance and accountability but greatly minimizes fiscal horizontal imbalances.

Blom-Hansen (1999) identifies horizontal imbalances with fiscal instability in especially poorly resource-endowed local governments. The findings will therefore help local communities to appreciate available services and support local revenue contributions accordingly.

\section{Study Limitations and Areas for Future Research}

Like any other research, this study is not free from limitations. First, it was conducted using a cross-sectional design. Cross-sectional methodology entails collecting data at one point in time. Such snapshot approach renders inference to causality results challenging (Baruch \& Holtom, 2008; Simonton, 2003). Future studies may adopt either random-sampling experimental approach or longitudinal methodology in order to investigate variable causality more effectively (Marsh et al., 2004; Scandura, \& Williams, 2000).

Second, the study tested possible entity location mediation in the budgetary institutional adjustments-fiscal discipline relationship. Its data did not support the mediation hypothesis (H4) when tested by both the Kenny et al. (1998) SEM-based path analysis direct and indirect effects approach, and through bootstrapping (Beran \& Srivastava, 1985; Bollen \& Stine, 1992; Preacher et al., 2010). Nonetheless, much as the dual mediation tests statistically dispel entity location mediation probability, more research is required to investigate it further.

Additionally, there may be more mediators and even moderators which could emerge in local government budgetary institutional adjustments-fiscal discipline relationship. For instance, factors such as entity autonomy and manpower technical capacity may be important for future studies investigation. The studies can also conduct follow-up analysis of specific local entities known for fiscal discipline challenges or excellence in other regions of Uganda. This will strengthen both literature and theory quite significantly.

In summary, the findings of this study intend to inspire upcoming fiscal discipline research in similar entities not only in Uganda and the Sub-Saharan Africa region but also elsewhere where fiscal federalism is seriously unfolding. The resultant motivation may engender accountability, transparency and quality service delivery especially in resource-constrained and complex economies of the developing world. 


\section{References}

Alesina, A., Hausmann, R., Hommes, R. \& Stein, E. (1999). "Budget Institutions and Fiscal Performance in Latin America", Working Paper 394, IDB OCE, Washington.

Alesina, A. \& Perotti, R. (1996). "Fiscal Discipline and the Budget Process", American Economic Review, 86(2), 401-407.

Altunbas, Y. \& Tornton, J. (2012). "Fiscal decentralization and governance", Public Finance Review, 41 (1), 66-85.

Bahl, R. \& Bird, R. (2008). "Subnational taxes in developing countries: The way forward", Public Budgeting and Finance, 28(4), 1-25.

Baruch, Y., \& Holtom, B. C. (2008). "Survey response rate levels and trends in organizational Research", Human Relations, 61, 1139-1160.

Beran, R., \& Srivastava, M. S. (1985). "Bootstrap tests and confidence regions for functions of a covariance matrix", Annals of Statistics, 13, 95-115.

Bird, R. (2011). "Subnational taxation in developing countries: A review of the literature", Journal of International Commerce, Economics and Policy, 2(1), 139161

Blom-Hansen, J. (1999). "Policy-making in central-local government relations: Balancing local autonomy, macroeconomic control, and sectoral policy goals", Journal of Public Policy, 19(3), 237-264.

Bollen, K.A., \& Stine, R.A. (1992). "Bootstrapping goodness-of-fit measures in structural equation models", Sociological Methods \& Research, 21, 205-229.

Bradford, D. \& Oates, W. (1971). "The analysis of revenue-sharing in a new approach to collective fiscal decisions", Quarterly Journal of Economics, 85, 416-439.

Ebel, R. \& Taliercio, R. (2005). "Subnational tax policy and administration in developing economies", Tax Notes International, 37(1), 919-936.

Fjeldstad, O-H. (2006). "Local revenue mobilization in urban settings in Africa", Local governance and poverty reduction in Africa (Tunis, Tunisia: Joint Africa Institute, (Eds.) Millett, K., Olowu, D. \& Cameron, R., 105-126.

Krogstrup, S. \& Wyplosz, C. (2006). "A common pool theory of deficit bias correction", European Economy, 275, 1-29.

Marsh, H.W., Hau, K.T. \& Wen, Z. (2004). "In search of golden rules: Comment on hypothesis-testing approaches to setting cut-off values for fit indexes and dangers in overgeneralizing $\mathrm{Hu}$ and Bentler's (1999) findings". Structural Equation Modeling: A Multidisciplinary Journal, 11(3), 320-341.

Ministry of Local Government (2017). Annual Report, Government Printers, Entebbe, Uganda. 
Olowu, D. (2003). "Local institutional and political structure and processes: Recent experience in Africa", Public Administration and Development, 23(1), 41-52.

Poterba, J. (1994). "State responses to fiscal crisis: The effects of budgetary institutions and politics", Journal of Political Economy, 102(4), 799-821.

Preacher, K.J., Zyphur, M.J., \& Zhang, Z. (2010). “A general multilevel SEM framework for assessing multilevel mediation", Psychological Methods, 15, 209-233.

Rodden, J. (2002). "The dilemma of fiscal federalism. Grants and fiscal performance around the world", American Journal of Political Science, 46(3), 670-687.

Scandura, T.A., \& Williams, E.A. (2000). "Research methodology in management: Current practices, trends, and implications for future research", Academy of Management Journal, 43, 1248-1264.

Simonton, D.K. (2003). "Qualitative and quantitative analyses of historical data", Annual Review of Psychology, 54, 617-640.

Tiebout, C. (1956). "A Pure Theory of Local Expenditures", Journal of Political Economy, 64, 416-424.

Von Hagen, J. \& Harden, I.J. (1995). "Budget Processes and Commitment to Fiscal Discipline", European Economic Review, 39, 771-779.

Winer, S. (1980). "Optimal fiscal illusion and the size of government", Public Choice, 35, 607-622.

Yilmaz, S. \& Serrano-Berthet, R. (2010). "Linking local government discretion and accountability in decentralization", Development Policy Review, 28(3), 259-293. 